\title{
Introduction
}

We wish to favour those who have been oppressed, so as to make them leaders and successors and establish them firmly in the world.

(al-Qur'an, 28:5-6)

We have sent Our Messengers with Clear Signs as well as the Book and the

Balance so that people may establish justice. (al-Qur'an, 57:25)

Those who believe and do not impair their belief with injustice, for them there

is peace and they are the guided ones. (al-Qur'an, 6:82)

\section{THE VISION OF ISLAM}

The primary vision of Islam in this world, as clearly enunciated by the Qur'an, is to be a 'blessing for mankind'1 (21:107). A number of Qur'anic verses, three of which have been quoted above, elaborate further the different aspects of this same vision. They emphasize the imperative of not only establishing justice and removing oppression but also uplifting the condition of the downtrodden to enable them to lead a more productive life that could help them become firmly established in this world as leaders and their successors. This is necessary not only to ensure social harmony and long-lasting peace in this world but also to vindicate three of the other most fundamental principles of the Islamic worldview.

One of these three principles is that all human beings, irrespective of their race, wealth, position, sex, age or nationality, are members of a single human family (ummah wahidah) as a result of their being created by the One and Only God and being offsprings of the same parents, Adam and Eve (al-Qur'an, 2:213 and 10:19). They are, thus, brothers and sisters with respect to each other and must, therefore, treat everyone fairly and caringly without any discrimination. The second principle is that they are also khalifahs or vicegerents of God on earth (al-Qur'an, 2:30). While being the khalifahs of the Creator of this universe is undoubtedly a great honour, it is also an immense responsibility. It makes it obligatory for them to try their best to fulfil their primary mission of being a 'blessing' for not only themselves but also everyone and 
everything else, including animals, birds, insects and the whole environment. Third, the resources that they have at their disposal do not really belong to them; they are rather a trust in their hands from God, their Creator (al-Qur'an, 57:7), for the purpose of being developed and utilized 'efficiently' and 'equitably' for the well-being of all members of the human family and, in particular, those who have been oppressed, as enjoined in the Qur'anic verse quoted above (28:5-6). The financial system cannot be an exception. It must also be a blessing for all by utilizing the resources at its disposal in a way that would help realize the well-being of all and not just a selected few (now being generally referred to as the top one per cent).

\section{The Failure of Muslims to Realize this Vision}

Muslim countries do not, however, reflect this vision of Islam at present. There is poverty and unemployment along with a great deal of exploitation and immense inequalities of income and wealth. Even the basic needs of all people do not get fulfilled. ${ }^{2}$ A number of Islamic values are being generally violated, particularly by the political elite and the rich and powerful. The well-being of most people, and particularly of the poor and vulnerable, is accordingly not being ensured. Muslims have, thus, failed to become a blessing for even themselves, leave alone the vision of becoming a blessing for also the rest of mankind as envisaged by the Qur'an. What could be the reason for this disappointing performance?

There are a number of moral, socio-economic, political and historical factors that may be able to help explain the prevailing state of affairs. ${ }^{3}$ The giving of attention to primarily economic variables may not, therefore, be sufficient. It is necessary to pursue a policy of comprehensive development - development that incorporates all the relevant aspects of moral, educational, socio-economic and political life and does not concentrate primarily on a rise in the aggregate level of output. ${ }^{4}$ It should also take into account the different constituents of development as well as the distribution of its benefits. One of the primary goals should be to ensure the availability of adequate employment and self-employment opportunities, particularly for the youth, because youth unemployment shatters their dream for the future and can be a source of great social turmoil and political instability. Without ensuring such comprehensive development, it may not be possible to translate into reality the crucial Islamic goal of overall human well-being (falah) to be attained through material as well as spiritual uplift, socio-economic justice, spread of moral and material education, technological advance, good governance, and family and social solidarity. 
As a result of centuries of decline, lack of proper education, political illegitimacy, misuse of resources, foreign occupation, and the pursuit of inappropriate policies, the vision has not been realized. It has, consequently, not been possible to attain the need fulfilment of all as well as the kind of family and social solidarity that is enshrined in the teachings of Islam. Moral decline along with crime and social unrest have also been generally on the rise.

Persistently high rates of poverty, unemployment, and glaring disparities in the living standards of the rich and the poor are not only a stigma on the face of humanity but also one of the surest ways of aggravating social discontent and unrest, which are already prevalent not just in most Muslim countries but also in a number of other countries, including some of the relatively rich economies. One of the manifestations of this social discontent is the 'Occupy Wall Street Movement', which took place in New York on 17 September 2011 as a protest against poverty, high rates of unemployment, family disintegration, and social and economic inequality. The simultaneous persistence of these problems in a number of countries around the world clearly reflects the gravity of the prevailing situation. Unless there is comprehensive moral, social, educational, economic and political reform and the condition of the needy and the unemployed improves appreciably, the Movement, which has so far been peaceful, carries the risk of degenerating into violence.

\section{THE CRUCIAL IMPORTANCE OF JUSTICE}

The 'Occupy' Movement is, thus, a clear reflection of the social and economic injustice prevailing in a number of countries around the world, including most of the Muslim countries, when the Qur'an has emphatically and unequivocally stressed the crucial importance of justice in society. Accordingly, the primary mission of all the messengers of God was to establish justice in this world (al-Qur'an, 57:25). The absence of justice is considered by the Qur'an to be one of the primary causes of decline and disintegration (20:111). The Qur'an has accordingly warned that it is not possible for a society to maintain social peace and harmony if the faith of its people gets tainted by injustice. This and several other Qur'anic verses have, therefore, clearly and emphatically laid down the absolute and unconditional moral imperative that justice has to be the hallmark of a genuinely Muslim society and that it is not possible for a Muslim society to reflect faithfully the ethos of Islam if justice does not prevail in all its different aspects of life. ${ }^{5}$ 
This message of the Qur'an has also become reflected in the Prophet's Sunnah (peace and blessings of God be upon him). He equated the absence of justice with 'absolute darkness' in the Hereafter. ${ }^{6}$ The darkness in the Hereafter will be nothing but a reflection of the darkness that we have perpetuated in this world through injustice, which does not only make the life of the affected individuals miserable but also accentuates social conflict, tension and crime. All of these tend to undermine brotherhood and solidarity, which are inalienable constituents of the ethos of Islam (al-Qur'an, 3:103-105), and ultimately hurt development, perpetuate poverty, and aggravate human problems. Consequently, injustice becomes even more entrenched and the needs of all people do not get satisfied adequately.

This categorical imperative of the Qur'an and Sunnah has also become reflected in the writings of nearly all Muslim scholars throughout history. For example, Mawardi (d. 1058) asserted that 'there is nothing that destroys the world and the conscience of the people faster than injustice'. ${ }^{7}$ Ibn Taymiyyah (d. 1328) emphasized that 'injustice is absolutely not permissible, irrespective of whether it is to a Muslim or a nonMuslim or even an unjust person'. ${ }^{8}$ Ibn Khaldun (d. 1406) weaved a whole philosophy of history around the role of justice in the rise and fall of a civilization and stated unequivocally that it is not possible for a society to achieve and sustain development without justice. ${ }^{9}$ This is also reflected in the writings of nearly all modern scholars.

\section{The Role of the Financial System in Promoting Justice}

In view of this crucial importance of justice in the Islamic worldview, every effort needs to be made to ensure its prevalence in Muslim societies if they wish to be assured of social peace and harmony and sustainable development. It is, hence, the moral obligation of all sectors of the polity, society and economy of a Muslim society, including the financial system, to contribute towards its actualization.

Banks have a particularly crucial role to play in ensuring justice. They mobilize resources from a large spectrum of the population, and justice demands that these resources should also be employed by them in such a way that the benefit permeates to the whole society. They have, however, not been able generally to live up to this expectation. They have unintentionally accentuated inequalities by mobilizing resources from a large spectrum of the population and making them available generally to a relatively much smaller spectrum of high net-worth individuals. This does not necessarily mean that the banks should make credit available to as large a spectrum of society as that of the depositors. This may not only 
be very risky but also may not be practical. What is expected of them, however, is to utilize these resources for granting loans and making investments in such a way that a large spectrum of the society is able to benefit from them directly or indirectly through the:

1) Promotion of employment and self-employment opportunities;

2) Promotion of medium and small enterprises as much as possible;

3) Expansion in the production of need-fulfilling and investment goods and services;

4) Reduction as much as possible in the prevailing income and wealth gaps between the rich and the poor; and

5) Minimization of inflationary pressures by ensuring that credit is granted and utilized for productive, and not speculative, purposes.

In contrast with this, the general impression around the world seems to be, as stated above, that the resources mobilized by banks from a large spectrum of society tend to go generally to a relatively much smaller spectrum without due regard for the impact of this on development with justice - development that leads to expansion in job opportunities and need fulfilment along with improvement in the distribution of income. While bank credit has accomplished a great deal that is good and constructive, it has also promoted conspicuous consumption, living beyond means, and exacerbation of inequalities of income and wealth in practically all countries around the world. This is one of the major reasons why, in spite of progressive taxation and the welfare role played by a number of governments, the distribution of income has generally failed to improve significantly in most countries around the world and the needs of all people do not get adequately satisfied.

In the United States, a substantial part of the total credit extended by banks goes to the largest non-financial corporations, which exercise significant political power at both state and federal levels. ${ }^{10}$ The Patman Report and the Securities and Exchange Commission Report in the late 1960s and early 1970s had drawn similar conclusions. ${ }^{11}$ Although financial institutions generally deny that they exercise significant influence over non-financial corporations to which they supply capital, one would tend to agree with Kotz's observation that 'historical experience indicates that such assurances cannot be taken at face value'. ${ }^{12}$ There is so far no indication to lead one to believe that the condition has changed significantly since then.

The position is most probably worse in a number of Muslim and other developing countries because of weak democratic institutions, greater political corruption, lack of a proper vision about the role of banks in the 
economy, and ineffective regulatory and supervisory framework for banks. For example, in Pakistan, 77.6 per cent of the total bank advances went to less than 1 per cent of total borrowers in 2002 when large depositors provided only 24.8 per cent of total deposits. Consequently, small borrowers received far less than what small depositors had contributed to the banks. It is even worse in nationalized banks where politically well-connected and influential borrowers are sometimes even able to get their loans written off. ${ }^{13}$ Such injustice tends to prevail in nearly all countries around the world, more so in countries where the regulatory and supervisory framework for financial institutions is inadequate and the political system promotes cronyism.

Given such inequalities in the allocation of credit, one can only expect inequalities of income to continue to rise rather than decline in the future - an outcome which is grossly in conflict with the socio-economic goals of all societies and particularly those of Islam. While the Basle Committee on Banking Supervision has made valuable recommendations for improving the quality of banking supervision worldwide and, thereby, helping strengthen the financial system, its mandate did not include the making of recommendations for promoting greater justice in the financial system. It is, therefore, imperative that, along with the effort to strengthen the financial system, an effective strategy is also adopted to promote an allocation of credit that is in tune with the universally cherished goal of promoting greater justice.

\section{How Can the Financial System Help Promote Justice?}

This raises the question of how to enable the financial system to promote greater justice in society. This does not necessarily require that credit be made available to as large a spectrum of society as that of the depositors. It does, however, require that the resources mobilized by the banks from a large spectrum of society be utilized in such a way that the interest of a large spectrum of the society is served. This would happen if the banks granted credit and pursued their investments in a way that helps further general well-being by promoting the kind of development that leads to an expansion in employment and self-employment opportunities as well as the production of need-fulfilling and investment goods and services.

There seems to be no justification for using the resources provided by a large spectrum of the population in a way that serves primarily the interests of the rich and makes them richer without making any worthwhile contribution towards the goal of expanding employment and self-employment opportunities and promoting development with justice. Credit should under no circumstances be provided for speculation and 
gambling in the commodity, stock and foreign exchange markets or for hoarding of essential goods to create an artificial shortage and raise prices. If the banks do not live up to this expectation with the resources that they have at their disposal, they cannot become a 'blessing' which the Creator of this universe wishes all human beings to be. Lack of adequate employment and self-employment opportunities can only exacerbate poverty which carries the potential of promoting incapacity, helplessness and, possibly, even crime. The Prophet (pbuh) has, hence, rightly warned that poverty carries the risk of driving a person close to disbelief. ${ }^{14}$ Removal of poverty, fulfilment of the basic needs of all individuals, and expansion of employment and self-employment opportunities for all in keeping with their ability and willingness to work should, therefore, be among the primary goals of public policy in all countries. The financial system cannot be an exception.

The financial system should try its best to help realize these goals. This is because the persistence of poverty has the effect of driving a person to begging which is in clear violation of the dignity that is inherent in the status of human beings as the khalifahs or vicegerents of God on earth. Begging has, accordingly, been looked down upon in almost all societies and prohibited by Islam except for those who are unable to earn a living because of some disability. ${ }^{15}$ An indispensable part of the vision of all societies has, therefore, generally been to enable people to earn an honest living to support themselves and their families. ${ }^{16}$ The only exceptions are those who have a disability that prevents them from doing so. For such people every society needs to have a proper social safety net to enable them to fulfil their needs without having to beg. Some welfare-oriented societies have already accomplished this. There is no reason why the Muslim world cannot do this if there is political will, the right policies are pursued for this purpose, and the wealthy realize their Islamic obligation towards those who are in need of their help from the wealth that does not really belong to them but is rather only a trust in their hands from God, its real owner.

A well-known legal maxim of Islamic jurisprudence (Qawa'id al-fiqhiyyah) stipulates that 'Something without which an obligation cannot be fulfilled is also obligatory'. ${ }^{17}$ Since it is not possible for a person to earn a living without having some skill in demand, the Prophet (pbuh) has enjoined Muslims to acquire skill in some suitable profession so that they can earn a respectable living. ${ }^{18}$ Unemployment has, nevertheless, become one of the most serious problems of most Muslim societies just as it has of many other societies around the world. This problem cannot, however, be solved without pursuing the kind of 
development that leads to an expansion in employment and selfemployment opportunities and fulfilment of the people's basic needs. It is, therefore, the collective obligation of both the public and private sectors of a Muslim society to facilitate the training of people in the kind of morally acceptable professions that are in demand and to pursue the kind of development that helps expand the availability of such opportunities. It is only the pursuit of such a policy that would make it possible for anyone who is able and willing to work to find a suitable job to earn an honest living in keeping with his/her ability.

This establishes a crucial role for banks who mobilize a substantial part of the economy's financial resources. They need to utilize these resources in a way that would help promote the kind of development that can help expand employment and self-employment opportunities, fulfil needs and reduce inequalities. This may not be possible unless the banks have a vision of what their responsibility is with respect to the realization of the humanitarian goals of their society.

This may naturally raise in the reader's mind the question of why should the banks be loaded with such a responsibility. Shouldn't their primary objective generally be, like that of other business organizations, to maximize their profit by effectively performing their generally recognized role of intermediation between savers and investors. The pursuit of these higher objectives does not appear to be a widely accepted responsibility of other business organizations and, if imposed on banks, it would tend to create a serious obstacle in the way of satisfying the objectives of their shareholders and other stakeholders. Such an attitude about banks does not appear to be appropriate because they are different from other business organizations. Accordingly, there are a number of reasons to believe that their primary objective should not be to pursue intermediation of any kind. They should, rather, pursue intermediation of the kind that would help their society realize some of its crucial goals. Two of these reasons are of particular significance.

One of these is that a preponderant part of their funds does not come from their own shareholders. It comes rather from the deposits provided to them by a large spectrum of society. It is, therefore, fair to expect that, while there is no harm in the banks trying to earn a reasonable amount of profit, they should try to do so in a way that would help serve the interest of a large spectrum of their society. This they can accomplish by helping actualize their society's crucial goals, some of which are:

1) Promoting a high but sustainable rate of development in conformity with the vision of their society;

2) Expanding employment and self-employment opportunities; 
3) Increasing the supply of need-fulfilling as well as investment goods and services;

4) Reducing the concentration of wealth in a few hands; and

5) Minimizing inflationary pressures.

If the banks use the depositors' resources in a way that hurts the realization of these goals, then they would be violating a trust that has been put in their hands - the trust of utilizing the society's resources for the benefit of the society as a whole. The violation would be even more severe if they also exacerbate inflationary pressures by expanding credit for speculative purposes rather than the growth of the real sector. It is imperative that the banks fulfil this obligation on their own volition as a part of their Islamic as well as corporate responsibility without being subjected to regulatory or supervisory controls. However, if they persist in not doing so, then the central bank would be justified in correcting the situation through persuasion and, if necessary, regulation and supervision.

A second reason for the difference is that by identifying themselves as 'Islamic', the banks have automatically accepted the moral imperative of helping their society realize some of the crucial goals of Islam which generally go under the title of maqasid (goals of) al-Shari 'ah. ${ }^{19}$ This necessitates that they should keep an eye not just on their own profit but also on their Islamic responsibility to extend credit primarily for purposes that would help their society realize some of these goals, particularly the goals of promoting sustainable development with particular emphasis on expanding employment and self-employment opportunities, productive investment and need fulfilment. If, in spite of identifying themselves as 'Islamic', they do not try earnestly to live up to this expectation and indulge in financing speculation and consumption of status symbols, then they would be violating a trust placed in their hands. In societies where the proportion of young people in the population is rising at a relatively high rate and the need for expanding employment and self-employment opportunities is also rising in step with this, the banks cannot remain oblivious to the fulfilment of this crucial need of their society. It is their Islamic as well as corporate responsibility to help their society as much as possible to fulfil this need.

\section{The Real World Scenario}

Data are not available to enable one to judge whether the operations of Islamic banks are, or are not, in harmony with this expectation. The general perception, however, seems to be that, even though the deposits of banks come from a large spectrum of the population, the benefit of 
these deposits does not normally tend to pervade to a reasonably large spectrum of the society even in the case of Islamic banks. It tends to go generally, as in the case of conventional banks, to a much smaller spectrum of relatively high net-worth individuals and businesses without due regard for the dire need of their society to promote development with justice. While it is not possible for the banks to provide credit to as large a spectrum of the population as that of the depositors, it should certainly be possible for them to extend credit in a way that serves the interest of a large spectrum by promoting the kind of development that leads to an expansion in employment and self-employment opportunities as well as an increase in the supply of need-fulfilling and investment goods and services. This shortcoming of banks has had the unintended effect of aggravating the already existing inequalities and social tensions in a number of countries. It is just like diverting, intentionally or unintentionally, water from numerous small rivers to a few large farms, thus making them thrive at the expense of a large number of small farms which also need this water but are unable to get an equitable share. In addition to this imperative of equitable disbursement of credit, it is also necessary to ensure that credit is extended primarily for productive proposes that would help promote employment and self-employment opportunities and increase the supply of need-fulfilling and investment goods and services. This is what would help the banks make a valuable contribution towards the accelerated development of their society with justice and, thus, becoming a blessing as required by Islam.

The performance of such a role does not seem to constitute a priority in the case of most Islamic banks just as it is in the case of most conventional banks. The general perception seems to be that the Islamic banks do not have any inhibition in providing financing for status symbols just like any other bank. This is in sharp contrast with what is required for the actualization of the maqasid. It is the responsibility of Islamic banks to help their society actualize these goals. In addition, the internationally recognized goals of ensuring safety of the depositors' funds and health and stability of the financial system should also be among their primary objectives and should not be neglected under any circumstances.

In addition to a general deficiency in the vision of both conventional as well as Islamic banks regarding the productive use and equitable distribution of credit, the allocation of credit in the conventional financial system suffers from another problem. This arises from the absence of risk-sharing which tends to create an incentive on the part of banks to extend credit excessively. Since it is now well-recognized that excessive lending is one of the major causes of financial crises, ${ }^{20}$ introduction of 
risk-sharing has become a clear imperative. Consequently, Islamic finance should be able to make a rich contribution to the international financial system if risk-sharing, which constitutes one of its fundamental principles, is conscienciously implemented by both Islamic and conventional banks. ${ }^{21}$

The effort to inject risk-sharing into the financial system should also have the effect of promoting greater discipline and efficiency into the system. This is because risk-sharing would tend to motivate the banks to be more careful in lending. It would, thereby, serve as a constraint not only on lending in excess of the borrowers' ability to repay, but also on promoting living beyond means and speculation. It would also have the effect of helping motivate investment depositors (who would also be sharing in the risk) to keep a close eye on the affairs of their banks to ensure greater transparency and more effective management. Risksharing should, thus, help improve loan quality and ensure a more effective use of bank resources. A built-in constraint in the financial system on excessive and imprudent lending, which is now generally recognized to be one of the major causes of financial crises and which Islamic finance is capable of helping bring about, should prove to be a great boon for the financial system.

The introduction of greater discipline need not, however, automatically lead to the flow of a higher volume of credit to small and medium enterprises (SMEs) which is necessary to inject greater justice into the system. The relatively greater potential of SMEs to expand employment and self-employment opportunities gives them a comparative advantage in every society where the population is large and young and the need for employment and self-employment opportunities is great. Nevertheless, they are generally at a great disadvantage in terms of getting financing from banks. It may not, however, be possible for them to benefit from this advantage of theirs if the necessary infrastructure for training, marketing and financing does not exist. It is, therefore, imperative for the governments to promote the necessary infrastructure so as to make it possible for banks to play a crucial role in providing microfinance to those SMEs which have a worthwhile project as well as the requisite expertise and reputation for creditworthiness.

This leads to the question of why the commercial banks are reluctant to extend credit to SMEs. There may be a number of reasons for this phenomenon. Two of these are more important. One is the higher cost of evaluating loan applications from a large number of SMEs and of managing and monitoring the loans once they have been extended. The 
other reason is the assumed greater risk of default. To enable the banks to give more credit to the SMEs, it is necessary to address both these reasons.

As far as the cost is concerned, there is no doubt that dealing with a large number of small entrepreneurs can be very cumbersome and expensive for banks. It is easier and more economical for them to lend relatively larger amounts to a few high net-worth clients who have adequate cash flow to ensure the repayment of their loans and are also considered to be more trustworthy. Such a practice, however, tends to lead to the unintended adverse consequence of making the rich richer. Even though data are normally not available to confirm this, it is generally understood to be the case almost everywhere around the world.

Among the few exceptions with respect to the availability of data is the State Bank of Pakistan which regularly publishes statistics on the distribution of deposits and advances by size. These statistics, indicate that, as partly reported earlier, small depositors who had deposits of less than one million rupees each and constituted 99.6 per cent of all depositors in 2002, contributed 61.3 per cent of total deposits. However, small borrowers, who borrowed less than one million rupees each and constituted 99.1 per cent of all borrowers, were able to get only 10.5 per cent of the banks' total advances. In sharp contrast with this, big depositors who had deposits of more than 10 million rupees each and constituted only 0.03 per cent of all depositors provided 24.8 per cent of total deposits. However, big borrowers borrowing more than 10 million rupees each and constituting less than 0.9 per cent of total borrowers were able to get 77.6 per cent of total advances. What this indicates is that big borrowers who constituted less than 1 per cent of the total borrowers were able to get more than three quarters of total advances when big depositors contributed only around one quarter of total deposits. Small borrowers, thus, received far less than what small depositors had contributed to the total pool of bank deposits. ${ }^{22}$ It is believed to be worse in nationalized banks where, as indicated earlier, a number of politically well-connected big borrowers are even able to get their loans written off.

Allocation of credit of this nature cannot but make the system more unjust by aggravating the prevailing high degree of inequalities in income and wealth. Such injustice seems to be prevalent in almost all countries around the world, in varying degrees. This is the result of a built-in bias in the financial system in favour of inequalities. It mobilizes savings from a large spectrum of society and makes them available to a relatively much smaller spectrum. Only a determined effort to reform the system can help reduce the extent of this bias. One of the most important tasks 
that needs attention, therefore, is the creation of an institutional framework that is necessary for reducing the cost of evaluation as well as the losses from loan default.

To reduce the cost, it is necessary for the central bank to make some arrangement for the establishment of a databank of all SMEs, and particularly of those who wish to get financing from banks. If they do not provide accurate data, they will be hurting their own long-run interest. The cost of collecting the data may be recovered from a fee charged to those to whom the data are supplied on a confidential basis. Aggregate data should however, be generally made available.

Only when greater justice is injected into the financial system and, thereby, headway is made toward the realization of the vision that the maqasid al-Shari'ah stand for, will it be possible to say that Islamization of the financial system has been really accomplished. If no perceptible progress is made in promoting risk-sharing and greater equity in the distribution of credit, expanding employment and self-employment opportunities, and reducing poverty and inequalities of income, then talking about the merits of Islamic finance may not carry much weight. This makes it necessary to evaluate the performance of Islamic financial institutions at least every five years to ensure that they are moving in the direction of helping realize the maqasid al-Shari 'ah.

\section{NOTES}

1. The word used in this Qur' anic verse is al-'alamin which is generally translated as 'mankind'. It, however, actually stands for all of God's creation and includes not only human beings but also animals, birds, insects and the whole environment. The implications of being a blessing for not only mankind but also all animate and inanimate objects as well as the environment need no elaboration. It is a moral obligation of all human beings to do whatever they can to enrich the environment, which is a trust in their hands, instead of polluting it.

2. See, for example, the 'Global Hunger Index' prepared by the International Food Policy Research Institute (IFPRI) (en.wikipedia.org/wiki/global_hunger_index). See also the unemployment rates in Muslim countries available in the World Factbook.

3. For a discussion of these factors, see Chapra (2008b).

4. For a basic introduction to the concept of comprehensive development in Islam, see Chapra (2008a).

5. See Chapra (1985), pp. 27-28.

6. Sahih Muslim (1955), Vol. 4, p. 1996:56, Kitab al-Birr wa al-Silah wa al-Adab, Bab Tahrim al-Zulm, from Jabir ibn 'Abdallah. The Prophet, peace and blessings of God be on him', has used the word zulumat in this hadith. Zulumat is the plural of zulmah which means darkness, and when used in its plural form, it signifies several layers of darkness, leading ultimately to 'pitch' or 'absolute' darkness, as is also evident in the Qur'anic verse, 24:40.

7. Al-Mawardi, Adab al-Dunya wa al-Din (1955), p. 125. 
8. Ibn Taymiyyah, Majmu' al-Fatawa (1961), Vol. 18, p. 166. See also his Minhaj al-Sunnah (1986), Vol. 5, p. 127.

9. Ibn Khaldun, Muqaddimah (n.d.), p. 287.

10. Kotz (1978), p. 143.

11. United States Congress, House Banking and Currency Committee, Subcommittee on Domestic Finance (1968), Commercial Banks and their Trust Activities: Emerging Influence on the American Economy, 90th Congress, 2nd Session, p. 5. United States, Securities and Exchange Commission, 1971, Institutional Investor Study Report, House Document 62-4 referred to the House Committee on Inter-State and Foreign Commerce, pt. 8, pp. 124-25.

12. Kotz (1978), p. 119.

13. Khwaja and Mian, 2005.

14. Reported by al-Bayhaqi from Anas ibn Malik in his Shu'ab al-Iman, Vol. 5, p. 267, No. 6612 (Cited by al-Suyuti (d. 911/1505) in his al-Jami'al-Saghir from Anas ibn Malik on the authority of Abu Nu'aym's al-Hilyah).

15. The Prophet (pbuh) prohibited begging by saying: 'Do not beg anything from people' (Abü Dawud, 1952, Vol. 1, p. 382, from 'Awf ibn Malik), and that 'The hand that is above is better than the hand that is below' (Al-Bukhārī. Vol. 2, p. 133, from 'Abdullah ibn 'Umar).

The Prophet (pbuh), also declared undesirable the giving of charity to those who are healthy and able-bodied and are, thus, capable of earning their own livelihood (Abū Dāwūd, 1952, Vol. I, p. 379; Nasā’̄î, 1964, Vol. 5, p. 74 and Ibn Mājah, 1952, Vol. İ. p. 589:1839).

$\mathrm{He}$, therefore, assigned a place of high esteem to earning one's own living by saying: 'He who seeks the world lawfully to refrain from begging, to cater for his family, and to be kind to his neighbour, will meet God on the Day of Judgment with his face shining like the full moon'.

(Tabrizi, Mīshkāt, 1381AH., Vol. 2, p. 658:5207, from Abū Hurayrah, on the authority of Bayhaqī's Shu 'ab al-İmān).

16. The Qur'an instructs Muslims to go out into the world and seek of God's bounties after having attended to their prayers (62:10). The Prophet (pbuh) said that: 'Earning a lawful livelihood is obligatory upon every Muslim' (Suyūtī, Aİ-Jami' al-Saghir, from Anas ibn Malik. p. 54). He elaborated this point further by saying: 'A man has not earned better income than that which is from his own effort' (Sunan Ibn Mājah, 1952, Vol. 2, p. 723:2138, from Miqdam ìbn Ma'di Karib). According to the Prophet (pbuh), trust in God does not imply that a Muslim should refrain from making an effort. He should in fact do his utmost, and then trust in God for the best results. This is the implication of his displeasure at a man who left his camel untied thinking that the camel would not stray because God would take care of him. The Prophet admonished him to tie the camel first and then trust in God (see 'Kitāb al-Kasb' of Muhammad Ibn al-Hasan al-Shaybān̄̄ in al-Sarakhsī, Kitāb al-Mabsūt, Vol. 30, p. 249.

Caliph 'Umar emphasized the Islamic injunction to earn one's own livelihood by saying that the sky does not rain gold and silver. God provides livelihood to people through the rendering of service to each other. Therefore no one should stay away from earning his livelihood ('Ali al-Tantawi and Naji al-Tantawi, Akhbaru 'Umar, p. 268).

17. 'Izz al-Din 'Abd al-Salam (n.d.), Vol. 1, p. 46; and al-Shatibi (n.d.), Vol. 2, p. 394; see also Mustafa al-Zarqa (1967), pp. 784 and 1088; and Nadvi (2000), Vol. 1, p. 480.

18. The Prophet (pbuh) said: 'God loves a Muslim who has a professional skill' (Narrated by al-Mundhiri, Vol. 2, p. 524, from Ibn 'Umar on the authority of al-Tabarani's al-Kabir and al-Bayhaqi). 
19. For some elaboration of the maqasid al-Shari'ah, see Chapra (2008).

20. See for example, Bank for International Settlements (2012), 82nd Annual Report (1 April 2011-31 March 2012) (Basel, 24 June), p. 26.

21. For an elaboration of this, see Chapra (2009).

22. Calculated from the data available in the State Bank of Pakistan, State Bank Bulletin.

\section{REFERENCES}

Al-'Abbadi, 'Abd al-Salam Dawud al- (1974, 1975 and 1977), Al-Milkiyyah fi al-Shari'ah al-Islamiyyah (Amman, Jordan: Maktabah al-Aqsa, 3 volumes), Vols 1-3.

Al-Qur'an - Translations are my own. I have, however, benefited from the translations of Marmaduke Pickthal and Abdullah Yusuf Ali.

Bank for International Settlements (2012), 82nd Annual Report (1 April 2011-31 March 2012) (Basel, 24 June), p. 26.

Bayhaqi, Imam Abu Bakr al- (d. 1065) (1990), Shu'ab al-Iman, Muhammad al-Sa'id Bisyuni Zaghlul (ed.) (Beirut: Dar al-Kutub al-'Ilmiyyah).

Bukhari, Imam Abu 'Abdallah Muhammad ibn Isma'il al- (d. 869) (1987), Sahih al- Bukhari, al-Shaykh Qasim al-Shamma'i al-Rifa‘i (ed.) (Beirut: Dar al-Qalam, 1987).

Chapra, M. Umer (2008a), The Islamic Vision of Development in the Light of Maqasid al-Shari'ah (Jeddah: IRTI/IDB).

Chapra, M. Umer (2008b), Muslim Civilization: The Causes of Decline and the Need for Reform (Leicester, UK: The Islamic Foundation).

Chapra, M. Umer (2009), The Global Financial Crises: Some Suggestions for Reform of the Global Financial Architecture in the Light of Islamic Finance (Kyoto: Research Centre for Islamic Area Studies).

Ibn Khaldun, 'Abd al-Rahman (d. 1406) (n.d.), Muqaddimah (Cairo: Al-Maktabah al-Tijariyyah al-Kubra).

Ibn Mājah (d. 886) (1952), Sunan Ibn Majah (Cairo: 'Isā al-Bābī al-Halabī).

Ibn Taymiyyah (1986), Minhaj al-Sunnah al-Nabawiyyah, M. Rashad Salim (ed.) (Riyadh: Imam Muhammad Islamic University).

Ibn Taymiyyah, Imam Ahmad (d. 1328) (1961), Majmu“ al-Fatawa Shaykh al-Islam Ahmad Ibn Taymiyyah, 1st edn, 'Abd al-Rahman al 'Asimi (ed.) (Riyadh: Matabi“ al-Riyadh).

International Food Policy Research Institute (IFPRI), Global Hunger Index (en.wikipedia, org/wiki/global_hunger_index).

'Izz al-Din 'Abd al-Salam (d. 1252) (n.d.), Qawa'id al-Ahkam fi Masalih al-Anam (Beirut: Dar al-Ma'rifah).

Khwaja, Asim and Atif Mian (2005), 'Do Lenders Favour Politically Connected Firms?: Rent Provision in an Emerging Financial Market', Quarterly Journal of Economics.

Kotz, D.M. (1978), Bank Control of Large Corporations in the U.S. (Berkeley: University of California Press).

Mawardi Abū 'Ali al- (d. 1058) (1955), Adab al-Dunya wa al-Din, Mustafa al-Saqqa (ed.) (Cairo: Mustafa al-Babi al-Halabi). 
Mundhiri, 'Abd al-'Azim al- (d. 1258) (1986), Al-Targhib wa al-Tarhib, Mustafa M. Al-Amarah (ed.) (Beirut: Dar al Kutub al-'Ilmiyyah).

Muslim, Imam Abu al-Husayn Muslim Ibn al-Hajjaj al-Naysaburiy (1955), Sahih Muslim, Muhammad Fu'ad 'Abd al-Baqi (ed.) (Cairo: 'Isa al-Babi al-Halabi).

Nadvi, 'Ali Ahmad al- (2000), Jamharah al-Qawa'id al-Fiqhiyyah fi al-Mu'amalat al-Maliyyah (Riyadh: Sharikah al-Rajhi al-Masrafiyyah li al-Istithmar).

Sarakhsi, Shams al-Din al- (d. 1090) (n.d.), Kitab al-Mabsut (Beirut: Dar al-Ma'rifah), particularly 'Kitab al-Kasb' of al-Shaybani in Vol. 30, pp. 24587.

Shatibi, Abu Ishaq, al- (d. 1388) (n.d.), al-Muwafaqat fi Usul al-Shari'ah (Cairo: al-Maktabah al-Tijariyyah al-Kubra).

State Bank of Pakistan, State Bank Bulletin, different relevant issues.

Suyuti, Jalal al-Din, al- (d. 1505) (n.d.), Al-Jami' al-Saghir (Cairo: 'Abd al-Hamid Ahmad Hanafi) Vol. 2.

Tabrīzī, Walī al-Dīn al- (1966), Mīshkāt al-Masabih, M. Nāsir al-Dīn al-Albānī (ed.) (Damascus: al-Maktab al-Islāmī).

Zarqa, Mustafa A., al- (1967), Al-Fiqh al-Islami fi Thawbihi al-Jadid (Damascus: Matabi`Alif Ba’ al-Adib). 